\title{
EFFECT OF SOIL AND FOLIAR APPLICATION OF IRON CHELATE ON NUTRIENT BALANCE IN LENTIL (Lens esculenta L.) BY USING MODIFIED DRIS EQUATION
}

Dalshad .A.Darwesh

Environmental Science, Department, College of Science, University of

Salahaddin -Erbil /Iraq.

dadaziz06@yahoo.co.uk

\begin{abstract}
A pot experiment was conducted to investigate the influence of two different Fe sources (Fe-EDTA and Fe-EDDHA) were sprayed on to the leaves and applied to the soil in levels were involved 0, 10, 20 and $30 \mathrm{mg} . \mathrm{l}^{-1}$ both fertilizers were sprayed to leaves two times, the interval date was 20 days and during spraying the soil surface were covered with plastics to prevent $\mathrm{Fe}$ contamination. The results indicated that there were significant effect $(\mathrm{P}<0.01)$ of the combination between types, concentration, and method of Fe application on total dry matter and on the concentration of $\mathrm{N}, \mathrm{P}, \mathrm{Ca}, \mathrm{Mg}, \mathrm{K}$ and Fe. The higher values of 6.24g.pot ${ }^{-1}$ and $30.98,3.54,33.81,28.43 \mathrm{mg} \cdot \mathrm{g}^{-1}, 246.67 \mathrm{mg} \mathrm{kg}^{-1}$ were recorded from combination treatment $\left(\mathrm{F}_{2} \mathrm{M}_{2} \mathrm{~L}_{2}\right)$ respectively, however the data revealed that the lowest nutrient balance index was recorded from combination treatment $\left(\mathrm{F}_{2} \mathrm{M}_{2} \mathrm{~L}_{2}\right)$ and attained 34.58 , while the higher NBI of (1028.45) was recorded in combination treatment $\left(\mathrm{F}_{1} \mathrm{M}_{2} \mathrm{~L}_{3}\right)$, also the result indicated that there are negative correlationship between the nutrient balance index and total dry weight were attained $(\mathrm{R}=-0.72)$.
\end{abstract}

\section{INTRODUCTION}

The foliar application of mineral nutrients by means of spray offers a method of supplying nutrients to higher plants more efficiently than methods involving root application when soil conditions are not suitable for $\mathrm{Fe}$ availability. In calcareous soils, for example, Fe availability is usually very low ,while Fe deficiency is widespread. Foliar spraying under these conditions could be much more efficient than any other applications of $\mathrm{Fe}$ to the soil (Horesh and Levy, 1981). In another study, amino acid chelated Fe applied to a pear cultivar by foliar spraying ameliorated $\mathrm{Fe}$ deficiency symptoms and increased total yield by $47 \%$ and Fe concentration of leaves by $120 \%$ (Kksal et al., 1999).Interactions between mineral elements in soil are one of the most important factors in affecting plant nutrient balance. It is known that there is certain competition between some nutrients, and an excess of a nutrient can affect the availability, uptake by plants and distribution in plant tissue; thus plant growth is affected negatively. In a study conducted by Karaman et al., (1997), the application of different Fe sources increased bean Fe concentration but decreased $\mathrm{P}, \mathrm{Zn}, \mathrm{Cu}$ and $\mathrm{Mn}$ concentrations. Baflar and Zgümüfl (1999) found a negative correlation between the total $\mathrm{Fe}$ concentration and $\mathrm{Cu}, \mathrm{Zn}$ and $\mathrm{Mn}$ concentrations of peach trees, and Fe concentration in leaves increased with sequestrene-138 Fe and Fe-sulfate applications. The chlorosis associated 
with Fe deficiency is not usually a direct consequence of an absolute lack of this as in the case of other micronutrient elements, but rather a secondary effect resulting from the complex interactions of $\mathrm{Fe}$ with other elements and various soil and environmental factors. Fe deficiency can occur in plants grown on alkaline soils that are rich in $\mathrm{Ca}$ and $\mathrm{Mg}$. Fe deficiency is also possible in soils with high concentrations of $\mathrm{Cu}, \mathrm{Mn}$ and $\mathrm{Zn}$ and in soils with low organic matter. Excess concentrations of $\mathrm{Cu}, \mathrm{Mn}$ and $\mathrm{Zn}$ in soil solution cause $\mathrm{Fe}$ deficiency. Similarly, high levels of $\mathrm{Fe}$ in soil can reduce plant uptake of $\mathrm{Cu}$, $\mathrm{Mn}$ and $\mathrm{Zn}$. Excessive $\mathrm{Ca}$ leads to deficiencies of Fe, B, Mn and Mg. Similarly, excessive phosphate anions can prevent Fe uptake and use by plants (Havlin et al., 1999). In a study conducted by Wikoff and Moraghan (1986) increasing levels of $\mathrm{Fe}$ application to the soil for eliminating $\mathrm{Fe}$ deficiency under unfavorable conditions for Fe availability resulted in Mn deficiency. In another study the Fe uptake and concentration of rice plants decreased with increasing levels of $\mathrm{Zn}$ in the soil (Alpaslan and Taban, 1996). A study was conducted to compare the residual solubilities of twelve Fe products when incubated with two calcareous soils. Iron, as ferrous sulfate, Fe-lignosulfonate (2 products), Fe-gluconate, Fe-glucoheptonate (3 products), Fe-EDTA, Fe-DTPA, FeEDDHA (2 products), and Fe-EDDHSA were incubated with two soils from 1 day to 8 weeks. Remaining $\mathrm{Fe}$ in the soil solution was determined after extraction with $0.01 \mathrm{M} \mathrm{CaCl}_{2}$. Negligible $\mathrm{Fe}$ from ferrous sulfate or $\mathrm{Fe}$ lignosulfonate remained in solution after 1 day of incubation. Iron from $\mathrm{Fe}$ gluconate or Fe-glucoheptonate was largely precipitated by 1 week of incubation, but measurable, levels of Fe from Fe-EDTA remained in solution for 4-8 weeks, depending on the soil. Only Fe-DTPA, Fe-EDDHA, and FeEDDHSA kept a significant amount of the applied $\mathrm{Fe}$ in solution for the duration of the experiment. They concluded that Fe-EDDHA should be an effective Fe fertilizer for alkaline soils, also it is probably best used for foliar, instead of soil application. Plant analysis is an important tool to establish the nutritional needs of crops, but requires a careful interpretation when using critical levels (Rosell et al.,1992). As plant nutrient concentrations are changing with the age of the plants diagnostic purpose, it is better to use nutrient ratio that remains quite constant throughout the plant cycle. These concepts are basic in Diagnosis and Recommendation Integrated System (DRIS). DRIS procedure was used to measure deviations of actual nutrient concentration ratios in plant tissues from the values of the same ratios previously established as reference values or norms. The international norms for N, P, and K, obtained by several authors (Sumner, 1981and Beverly, 1993) have been utilized. However, some researchers have suggested that norms which were calculated from a local data base may improve DRIS diagnosis (Dara et al., 1992). DRIS is a system of calculations by which the ratios of tissue nutrient concentrations in a sample are compared to optimum values of the same ratios in a high-yielding or otherwise desirable population, this system of calculation gives an index for each nutrient essentially, this nutrient index is a mean of the deviations of the ratios containing a given nutrient from their respective optimum or DRIS norms values .Each relationship between nutrients 
in a high-yielding or desirable group constitutes a DRIS norm and it has its respective mean and coefficient of variation. DRIS equation is used to calculate the relative index for nutrients that range from negative to positive values but always sum to zero. Negative indices indicate nutrient deficiency, positive indices indicate successive and zero indices indicated adequacy (Baldock and Schulte ,1996). DRIS also computes an overall index which is the sum of the absolute values of the nutrient indices called Nutrient Balance Index-NBI which expresses the nutritional balance of a crop under evaluation. The smaller the absolute sum (NBI), the lesser imbalance among nutrients. However the DRIS approach was designed to provide a valid diagnostic irrespective of plant age and tissue origin and cultivar and local conditions or changes in the method of tissue sampling or the time of sampling (Jones, 1993). DRIS approach has been studied by many investigators the first Iraq study carried out by AlKhafaji ,(1993), Esmail et al., (1999), and Sultan ,(2005)by using the tomato ,cucumber, pea and lentil .

The objective of this study was to examine the response of Lentil to $\mathrm{Fe}$ chelate source applied to soil and foliar and to investigate the index of some nutrient in relation to foliar and soil Fe applications by using modified DRIS equation.

\section{MATERIALS AND METHODS}

Plant materials:Lentil (Lens esculenta L.) cultivars were used in the present study. Fe solutions prepared from two different Fe sources (Fe-EDTA and FeEDDHA) were sprayed on to the leaves and applied to soil. Solutions of foliar applications were prepared as follows:- A $250 \mathrm{mg} .1^{-1}$ of each of Fe-EDTA and Fe-EDDHA, then $\left(0,10,20\right.$, and30 mg. $\left.\mathrm{l}^{-1}\right)$ perpetrated from the stock solution. The last volume was brought up to $1 \mathrm{~L}$ with pure water. However the same levels of (Fe-EDTA and Fe-EDDHA) used in foliar, applied to soil as powder, the study was conducted under green house conditions. Fe solutions (Fe-EDTA and Fe-EDDHA) were sprayed onto the leaves two times the interval date between two spray were 20 days. For the control treatment, pure water was sprayed on to the leaves. During spraying, the soils surface were covered with plastic to prevent Fe contamination. Plant analysis in order to determine some nutrient, leaf samples were collected after both application (before flowering stage). Leaf samples were collected as described by Cline (1962) and washed thoroughly with dilute acid $(0.2 \mathrm{~N} \mathrm{HCl})$ and pure water to remove surface $\mathrm{Fe}$ and other residues. The samples were dried at $65 \mathrm{C}^{\circ}$ and then wet digested in $\mathrm{H}_{2} \mathrm{O}_{2}$ and $\mathrm{H}_{2} \mathrm{SO}_{4}$ acid (1/1, v/v) mixture (Schuffelen and Vanschauwenburg, 1961). The $\mathrm{N}$ content was measured by the micro-Kjeldahl digestion method of Bremmer and Mulvaney, (1982), the $\mathrm{P}$ content was determined by the molybdenum blue colorimetric method of Black, (1965), Ca, Mg and Fe was determined by atomic absorption, the flame photometric method of Allen ,(1976) was used to determined K.

Soil properties: Some physical and chemical characteristics of the soil were determined according to methods described by Pansu and Gautheyrou, (2006). Table (1) 
Calculation of DRIS indices: the DRIS indices were calculated by using the following index equations by Hallmark et al., (1987):-

N-Index $=\frac{f(N / P)+f(N / K)+f(N / C a)+f(N / M g)+f(N / F e)+f(N / D M)}{n}$
P-Index $=\frac{-f(N / P)+f(P / K)+f(P / C a)+f(P / M g)+f(P / F e)+f(P / D M)}{n n}$
K-Index $=\frac{-f(N / K)-f(P / K)+f(K / C a)+f(K / M g)+f(K / F e)+f(K / D M)}{\text { Ca-Index }=\frac{-f(N / C a)-f(P / C a)-f(K / C a)^{n}+(\mathrm{Ca} / \mathrm{Mg})+f(\mathrm{Ca} / \mathrm{Fe})+f(\mathrm{Ca} / \mathrm{DM})}{n^{n}}}$

Mg-Index $=\frac{-f(N / M g)-f(P / M g)-f(K / M g)-f(C a / M g)+f(M g / F e)+f(M g / D M)}{n}$

Fe- Index $=\frac{-f(N / F e)-f(P / F e)-f(K / F e)-f(C a / F e)-f(M g / F e)+f(F e / D M)}{n n}$

DM-Index $=\frac{-f(N / D M)-f(P / D M)-f(K / D M)-f(\mathrm{Ca} / D M)-f(\mathrm{Mg} / D M)-f(\mathrm{Fe} / D M)}{n}$

$\mathrm{f}(\mathrm{X} / \mathrm{Y})=(\mathrm{X} / \mathrm{Y} / \mathrm{x} / \mathrm{y}-1) * 1000 / \mathrm{CV}_{\mathrm{x} / \mathrm{y}} \quad$ if $\mathrm{X} / \mathrm{Y} \geq \mathrm{x} / \mathrm{y}$

$\mathrm{f}(\mathrm{Y} / \mathrm{X})=(1-\mathrm{x} / \mathrm{y} / \mathrm{X} / \mathrm{Y})^{*} 1000 / \mathrm{CV}_{\mathrm{x} / \mathrm{y}}$ if $\mathrm{x} / \mathrm{y} \geq \mathrm{X} / \mathrm{Y}$

$\mathrm{X}$ and $\mathrm{Y}=$ nutrients

n- number of ratio

$\mathrm{x} / \mathrm{y}-$ mean for $\mathrm{X} / \mathrm{Y}$, in reference population (high-yielding treatment).

$\mathrm{CV}_{(\mathrm{x} / \mathrm{y})}$ - coefficient of variation for $\mathrm{x} / \mathrm{y}$, in reference population (high-yielding group).

$\mathrm{NBI}=$ The sum of absolute values of the nutrient indices

Table (1): Some physical and chemical properties of soil under study

\begin{tabular}{|c|c|c|}
\hline \multicolumn{3}{|c|}{ Soil properties } \\
\hline \multirow{3}{*}{$\begin{array}{c}\text { Particle Size } \\
\text { Distribution } \mathrm{g} \cdot \mathrm{Kg}^{-1}\end{array}$} & Sand & 250.4 \\
\hline & Silt & 400.6 \\
\hline & Clay & 349.0 \\
\hline Textural name & \multicolumn{2}{|c|}{ Clay loam } \\
\hline $\mathrm{pH}$ & \multicolumn{2}{|c|}{7.8} \\
\hline ECe dS.m ${ }^{-1}$ & \multicolumn{2}{|c|}{0.5} \\
\hline Organic matter g. $\mathrm{Kg}^{-1}$ & \multicolumn{2}{|c|}{17} \\
\hline Total $\mathrm{CaCO}_{3} \quad \mathrm{~g} \cdot \mathrm{Kg}^{-1}$ & \multicolumn{2}{|c|}{250} \\
\hline Total Nitrogen g. $\mathrm{Kg}^{-1}$ & \multicolumn{2}{|c|}{2.3} \\
\hline Available Phosphorus mg. $\mathrm{Kg}^{-1}$ & \multicolumn{2}{|c|}{5.6} \\
\hline EDTA extractable Fe mg. $\mathrm{Kg}^{-1}$ & \multicolumn{2}{|c|}{0.09} \\
\hline \multicolumn{3}{|c|}{ Cation meq.100g ${ }^{-1}$} \\
\hline
\end{tabular}




\begin{tabular}{|c|c|}
\hline Calcium & 11.00 \\
\hline Magnesium & 5.00 \\
\hline Potassium & 1.49 \\
\hline
\end{tabular}

Statistical analysis: The experiment was designed in completely randomized design with 3replications (factorial CRD).The experimental data were analyzed by ANOVA, the differences between the treatment means were separated by Tukye's test. (Steel and Torrie,1969).

\section{RESULTS AND DISCUSSION}

The data in Table (2) and Figure (1) indicated that there were significant effect of the combination between types, concentration, and method of $\mathrm{Fe}$ application on total dry matter and on the concentration of nitrogen ,phosphorus, calcium, magnesium, potassium and iron. The higher values of (6.24gm.pot ${ }^{-1}$ ) and 30.98, 3.54, 33.81, 3.33, 28.43mg.g ${ }^{-1}$, and 246.67mg. $\mathrm{kg}^{-1}$ were recorded from combination treatment $\left(\mathrm{F}_{2} \mathrm{M}_{2} \mathrm{~L}_{2}\right)$ respectively, while the lowest values were recorded from combination treatment $\left(\mathrm{F}_{2} \mathrm{M}_{2} \mathrm{~L}_{3}, \mathrm{~F}_{1} \mathrm{M}_{1} \mathrm{~L}_{2}\right.$, $F_{2} M_{2} L_{3}, F_{2} M_{1} L_{2}, F_{2} M_{1} L_{2}, F_{2} M_{2} L_{3}$ ) for above parameters respectively, however the soil application and spraying plants with Fe-EDDHA showed the highest dry weight , N, P, Ca, Mg, $\mathrm{K}$ and $\mathrm{Fe}$ as compared with those spraying with $\mathrm{Fe}$ EDTA. The higher values of above parameters, could be interpreted on the basis that the soil used in this study is a calcareous soil $\left(\mathrm{pH} 7.8\right.$ and $\mathrm{CaCO}_{3}$ $25 \%)$ and its well that the important

Table (2) :Combination effect of application methods, types of Fe chelate and their concentration on dry weight and nutrient concentration in lentil

\begin{tabular}{|c|c|c|c|c|c|c|c|}
\hline \multirow{2}{*}{ Treatments } & \multicolumn{6}{|c|}{ Nutrients concentration } & \multirow{2}{*}{$\begin{array}{l}\text { Total dry } \\
\text { weight } \\
\left(\text { gm.pot }^{-1}\right)\end{array}$} \\
\hline & $\begin{array}{l}\text { Nitrogen } \\
\left.\left(\mathrm{mg} \cdot \mathrm{g}^{-1}\right)\right)\end{array}$ & $\begin{array}{l}\text { Phosphorus } \\
\left(\mathrm{mg} \cdot \mathrm{g}^{-1}\right)\end{array}$ & $\begin{array}{l}\text { Calcium } \\
\left(\mathrm{mg}^{-1} \mathrm{~g}^{-1}\right)\end{array}$ & $\begin{array}{l}\text { Magnesium } \\
\left(\mathrm{mg} \cdot \mathrm{g}^{-1}\right)\end{array}$ & $\begin{array}{c}\text { Potassium } \\
\left(\mathrm{mg} \cdot \mathrm{g}^{-1}\right)\end{array}$ & 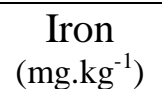 & \\
\hline $\mathrm{F}_{1} \mathrm{M}_{1} \mathrm{~L}_{0}$ & 13.12 & 1.72 & 24.52 & 2.40 & 16.77 & 93.33 & 2.20 \\
\hline $\mathrm{F}_{1} \mathrm{M}_{1} \mathrm{~L}_{1}$ & 11.79 & 1.49 & 28.37 & 2.84 & 20.10 & 112.00 & 1.63 \\
\hline $\mathrm{F}_{1} \mathrm{M}_{1} \mathrm{~L}_{2}$ & 7.94 & 1.46 & 26.87 & 2.34 & 17.07 & 117.33 & 1.70 \\
\hline $\mathrm{F}_{1} \mathrm{M}_{1} \mathrm{~L}_{3}$ & 21.67 & 2.48 & 24.66 & 3.02 & 23.83 & 149.00 & 3.93 \\
\hline $\mathrm{F}_{1} \mathrm{M}_{2} \mathrm{~L}_{0}$ & 10.21 & 1.65 & 28.65 & 3.20 & 15.90 & 87.00 & 1.46 \\
\hline $\mathrm{F}_{1} \mathrm{M}_{2} \mathrm{~L}_{1}$ & 12.49 & 1.43 & 23.21 & 2.68 & 18.40 & 118.00 & 1.61 \\
\hline $\mathrm{F}_{1} \mathrm{M}_{2} \mathrm{~L}_{2}$ & 20.39 & 3.00 & 26.73 & 2.85 & 26.20 & 172.33 & 3.54 \\
\hline $\mathrm{F}_{1} \mathrm{M}_{2} \mathrm{~L}_{3}$ & 8.29 & 1.85 & 25.56 & 2.27 & 20.87 & 70.00 & 2.18 \\
\hline $\mathrm{F}_{2} \mathrm{M}_{1} \mathrm{~L}_{0}$ & 12.31 & 1.57 & 32.36 & 2.34 & 16.17 & 89.33 & 2.15 \\
\hline $\mathrm{F}_{2} \mathrm{M}_{1} \mathrm{~L}_{1}$ & 14.67 & 2.16 & 33.25 & 3.22 & 20.57 & 118.33 & 1.70 \\
\hline $\mathrm{F}_{2} \mathrm{M}_{1} \mathrm{~L}_{2}$ & 13.77 & 1.72 & 22.46 & 1.85 & 21.20 & 129.33 & 4.67 \\
\hline $\mathrm{F}_{2} \mathrm{M}_{1} \mathrm{~L}_{3}$ & 27.72 & 2.73 & 33.67 & 2.84 & 28.10 & 210.00 & 2.62 \\
\hline $\mathrm{F}_{2} \mathrm{M}_{2} \mathrm{~L}_{0}$ & 11.61 & 1.73 & 33.53 & 2.77 & 16.27 & 83.33 & 2.52 \\
\hline $\mathrm{F}_{2} \mathrm{M}_{2} \mathrm{~L}_{1}$ & 14.93 & 1.56 & 33.81 & 2.21 & 18.33 & 123.33 & 2.93 \\
\hline $\mathrm{F}_{2} \mathrm{M}_{2} \mathrm{~L}_{2}$ & 30.98 & 3.54 & 32.63 & 3.33 & 28.43 & 246.67 & 6.24 \\
\hline $\mathrm{F}_{2} \mathrm{M}_{2} \mathrm{~L}_{3}$ & 9.98 & 1.39 & 29.58 & 2.99 & 18.67 & 54.67 & 1.46 \\
\hline
\end{tabular}




\begin{tabular}{|l|c|c|c|c|c|c|c|}
\hline Tukye's $(1 \%)$ & 4.43 & 0.53 & 5.24 & 1.70 & 4.15 & 32.91 & 1.42 \\
\hline
\end{tabular}

$\mathrm{F} 1=$ Fe-EDTA, $\mathrm{F}_{2}=$ Fe-EDDHA $\quad \mathrm{M}_{1}=$ Soil application , $\mathrm{M}_{2}=$ Foliar application Concentration mg. $1^{-1}=\mathrm{L}_{0}=0, \mathrm{~L}_{1}=10, \mathrm{~L}_{2}=20, \mathrm{~L}_{3}=30$

characteristics of calcareous soil are a high $\mathrm{pH}$ from 7 to 9 and significant content of free carbonates, when a plants that lacks certain metabolic abilities grow in calcareous soil it developed symptoms of iron chlorosis that result because $\mathrm{Fe}$ is not found in available form. Thus, the usual way in which limeinduced chlorosis is alleviated it by supply of iron chelates such as FeEDTA and FeEDDHA to the soil and foliage, but under this condition the FeEDDHA is more effectiveness than FeEDTA because the stability of FeEDTA at least is not high in calcareous soils also it may damage the leaves of plants, from the result obtained it could be concluded that plant fertilized with both fertilizers showed a depression in dry weight and nutrients contents such reduction may be due to the inadequacy in the growing media or to the decrease in water flow, since under such condition root pressure is reduced causing decrease in water flow that mean less water is taken up by the roots and transported to the shoots. Consequently less water and nutrients are available for normal growth and developments. Abou El-Nour, (2002) came to the same conclusion .It is interesting to note that spraying fertilizers can improve plant tolerance to salinity which result due to soil application of fertilizers by increasing root growth which leads to promote nutrients uptake.

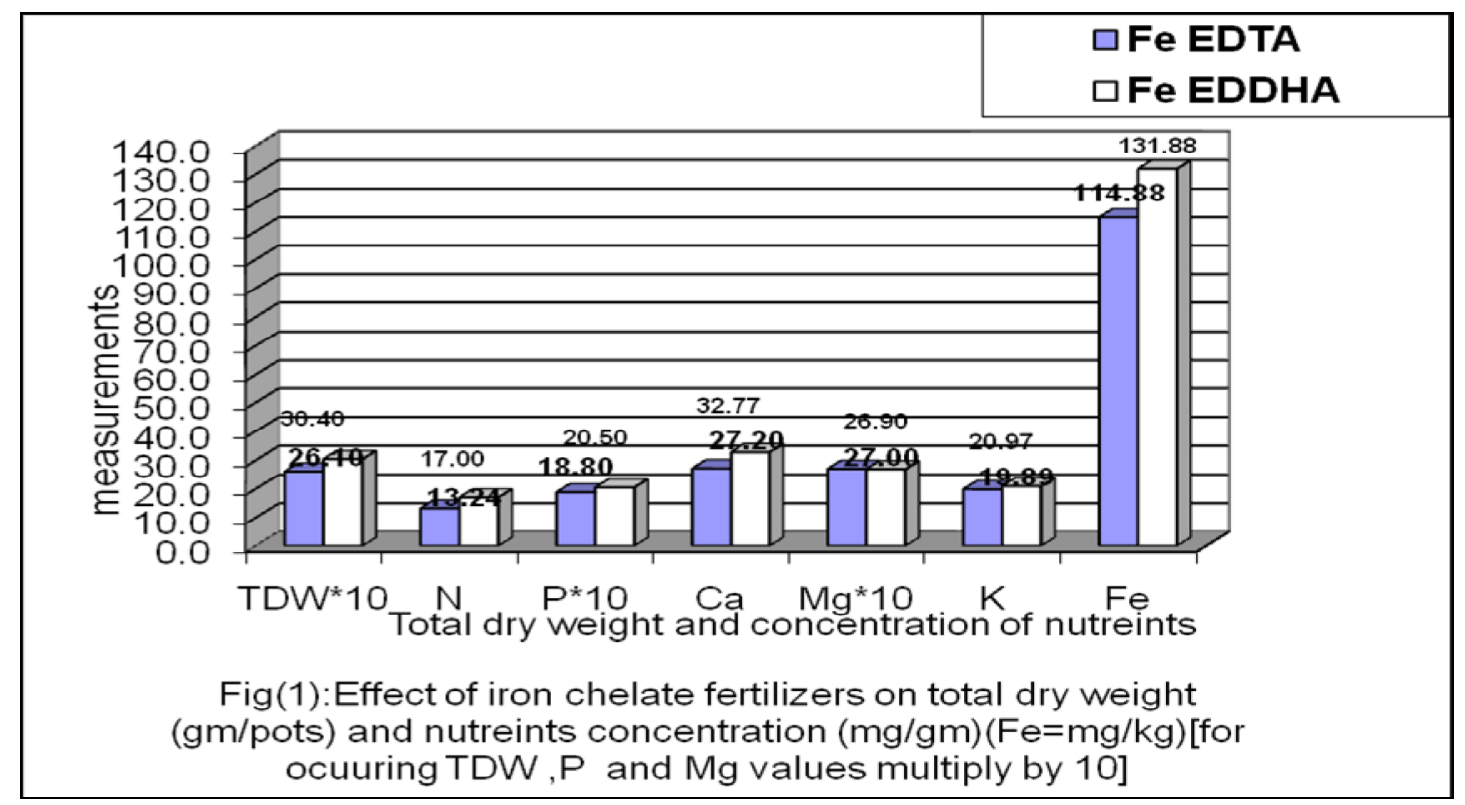

The data in (Table 3 and Figure 2) shows that the combination between types of Fe-chelate and their levels affected significantly( $\mathrm{p} \leq 0.05$ and 0.01$)$ on total dry matter and nutrients concentration. The highest values of dry matter and the concentration of $\mathrm{N}, \mathrm{P}, \mathrm{K}$, and $\mathrm{Fe}\left(5.46 \mathrm{~g}_{\mathrm{got}}{ }^{-1}\right.$ and 22.37, 2.63, 24.82 mg.gm ${ }^{-1}$ and $188 \mathrm{mg} \cdot \mathrm{Kg}^{-1}$ were recorded from combination treatments $\left(\mathrm{F}_{2} \mathrm{~L}_{2}\right)$ respectively except in case of $\mathrm{Ca}$ and $\mathrm{Mg}$ where the high concentration were recorded in combination treatments $\left(\mathrm{F}_{2} \mathrm{~L}_{1}\right.$ and $\left.\mathrm{F}_{2} \mathrm{~L}_{3}\right)$ respectively, while the 
lowest values 1.62 g.pot ${ }^{-1}$, and $1.46 \mathrm{mg} \cdot \mathrm{gm}^{-1}, 11.67 \mathrm{mg} \cdot \mathrm{gm}^{-1},\left(25.11 \mathrm{mg} \cdot \mathrm{gm}^{-1}\right.$, and $2.55,16.22 \mathrm{mg} \cdot \mathrm{gm}^{-1}$ and $86.33 \mathrm{mg} \cdot \mathrm{Kg}^{-1}$ for (total dry matter and P). $(\mathrm{N}),(\mathrm{Ca})$, and $(\mathrm{Mg}, \mathrm{K}$ and $\mathrm{Fe})$ were recorded from the combination treatment $\left(\mathrm{F}_{1} \mathrm{~L}_{1}\right),\left(\mathrm{F}_{1} \mathrm{~L}_{0}\right),\left(\mathrm{F}_{1} \mathrm{~L}_{3}\right)$ and $\left(\mathrm{F}_{2} \mathrm{~L}_{0}\right)$ respectively. This results interpreted on the ground that the foliar $\mathrm{Fe}$ application is effective way to increase the total dry matter and $\mathrm{Fe}$ concentration in leaves also the other nutrients particularly the $\mathrm{K}$, $\mathrm{Mg}$ and $\mathrm{N}$, this may be attributed to the cation and anion balance of ion uptake. Moreover, the plant uptake more cations than anions there is effluex of $\mathrm{H}^{+}$to corrects this imbalance, however the reasons may be due to that the iron constituents as cofactor of many enzyme such as catalase and peroxidase which involved in detoxification of $\mathrm{H}_{2} \mathrm{O}_{2}$ in chloroplast and cytosol , thus under iron deficient this process is reduced and the cell growth is depressed ,consequently the yield and nutrients content of plants are also reduced. Also foliar spray treatments with adequate concentration markedly increased all the macronutrient except $\mathrm{Ca}$ and $\mathrm{Mg}$. The recorded increase in macronutrients contents could be interpret through improving root growth and consequently leads to increase nutrients up take and translocation as well. It could be concluded that high and lower concentration of chelate Fe fertilizers adversely affected the growth of plants, this depression may be due to the dequenency of osmotic regulation induced by imbalance uptake of nutrients.

Table (3):Effect of difference levels of Fe-chelate on total dry weight and nutrients concentration in lentil plants

\begin{tabular}{|c|c|c|c|c|c|c|c|}
\hline \multirow[t]{2}{*}{ Treatments } & \multicolumn{6}{|c|}{ Nutrients concentration } & \multirow{2}{*}{$\begin{array}{l}\text { Total dry } \\
\text { weight } \\
\left(\text { g.pot }^{-1}\right)\end{array}$} \\
\hline & $\begin{array}{l}\text { Nitrogen } \\
\left(\mathrm{mg} \cdot \mathrm{g}^{-1}\right)\end{array}$ & $\begin{array}{l}\text { Phosphorus } \\
\left(\mathrm{mg} \cdot \mathrm{g}^{-1}\right)\end{array}$ & $\begin{array}{l}\text { Calcium } \\
\left(\mathrm{mg} \cdot \mathrm{g}^{-1}\right)\end{array}$ & $\begin{array}{c}\text { Magnesium } \\
\left(\mathrm{mg} \cdot \mathrm{g}^{-1}\right)\end{array}$ & $\begin{array}{c}\text { Potassium } \\
\left(\mathrm{mg} \cdot \mathrm{g}^{-1}\right)\end{array}$ & $\begin{array}{c}\text { Iron } \\
\left(\mathrm{mg} \cdot \mathrm{Kg}^{-1}\right)\end{array}$ & \\
\hline $\mathrm{F}_{1} \mathrm{~L}_{0}$ & 11.67 & 1.69 & 26.59 & 2.80 & 16.33 & 90.17 & 1.83 \\
\hline $\mathrm{F}_{1} \mathrm{~L}_{1}$ & 12.14 & 1.46 & 25.79 & 2.76 & 19.25 & 115.00 & 1.62 \\
\hline $\mathrm{F}_{1} \mathrm{~L}_{2}$ & 14.17 & 2.23 & 26.80 & 2.59 & 21.63 & 144.83 & 2.62 \\
\hline $\mathrm{F}_{1} \mathrm{~L}_{3}$ & 14.98 & 2.16 & 25.11 & 2.64 & 22.35 & 109.50 & 3.05 \\
\hline $\mathrm{F}_{2} \mathrm{~L}_{0}$ & 11.96 & 1.65 & 32.94 & 2.55 & 16.22 & 86.33 & 2.33 \\
\hline $\mathrm{F}_{2} \mathrm{~L}_{1}$ & 14.80 & 1.86 & 33.53 & 2.71 & 19.45 & 120.83 & 2.32 \\
\hline $\mathrm{F}_{2} \mathrm{~L}_{2}$ & 22.37 & 2.63 & 27.55 & 2.59 & 24.82 & 188.00 & 5.46 \\
\hline $\mathrm{F}_{2} \mathrm{~L}_{3}$ & 18.85 & 2.06 & 31.62 & 2.91 & 23.38 & 132.33 & 2.04 \\
\hline Tukye's $1 \%$ & 3.96 & 0.48 & 4.69 & 0.37 & 3.71 & 25.50 & 1.24 \\
\hline
\end{tabular}




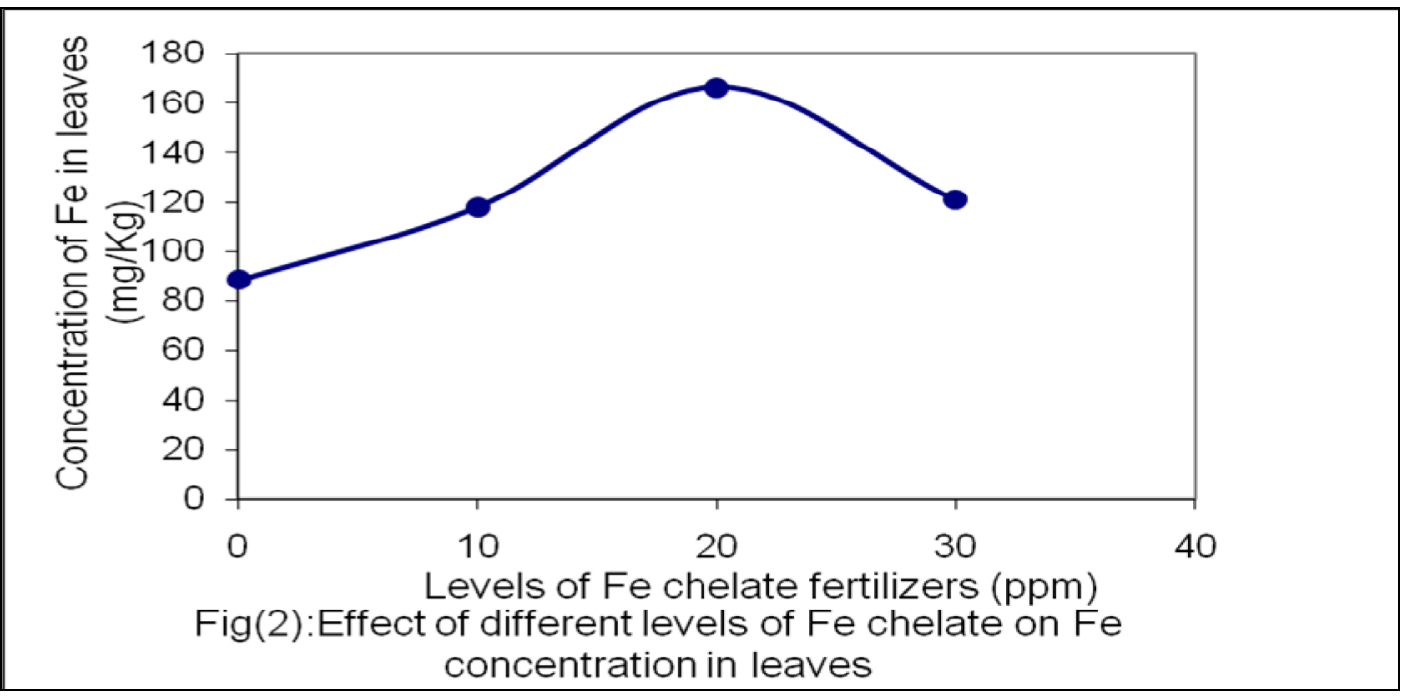

A nutrient index is a mean of the deviation from the optimum or norms values. The negative index values indicate that the nutrient levels are below the optimum. Consequently, the more negative index, the more deficient the nutrient, similarly a positive index indicates that the nutrient levels are above the optimum, and the more positive index the more excessive the nutrient that is relative to normal, and the DRIS index is equal to zero indicating that the nutrient is at optimum levels, but there are authors who do not consider a nutrient deficiency or excessive when the DRIS indices are negative or positives and near to zero. Soltanpour et al.(1995). The combination effect of types, methods and different concentration of Fe chelate fertilizers on nutrient indices and NBI in lentil plants are presented in Table(4). Means value of the data revealed that the lowest nutrient balance index was recorded from

\begin{tabular}{|l|l|l|l|}
\hline Treatments & Nutrient Indices & & \\
\hline
\end{tabular}

combination treatment $\left(\mathrm{F}_{2} \mathrm{M}_{2} \mathrm{~L}_{1}\right)$ and attained 34.58, if compared to control $\left(\mathrm{F}_{2} \mathrm{M}_{2} \mathrm{~L}_{0}\right)$ the NBI values was attained 560.89. As 


\begin{tabular}{|c|c|c|c|c|c|c|c|c|c|}
\hline & $\mathbf{N}$ & $\mathbf{P}$ & $\mathbf{C a}$ & Mg & $\mathbf{K}$ & $\mathbf{F e}$ & TDW & NBI & TDW (g.pot $\left.{ }^{-1}\right)$ \\
\hline$F_{1} M_{1} L_{0}$ & -57.97 & 55.57 & 54.53 & 30.95 & 51.69 & -96.69 & -38.09 & 385.49 & 2.20 \\
\hline$F_{1} M_{1} L_{1}$ & -119.10 & -51.93 & 74.90 & 48.00 & 114.77 & -1.05 & -65.59 & 475.35 & 1.63 \\
\hline $\mathbf{F}_{1} \mathbf{M}_{1} \mathbf{L}_{2}$ & -191.41 & -71.17 & 82.99 & 39.88 & 158.57 & 34.92 & -53.77 & 632.72 & 1.70 \\
\hline$F_{1} M_{1} L_{3}$ & -23.20 & 32.40 & 12.96 & 21.20 & 31.88 & -51.72 & -23.51 & 196.88 & 3.93 \\
\hline $\mathbf{F}_{1} \mathbf{M}_{2} \mathbf{L}_{0}$ & -104.94 & 52.41 & 91.71 & 68.86 & 81.88 & -115.92 & -74.00 & 589.72 & 1.46 \\
\hline $\mathbf{F}_{1} \mathbf{M}_{2} \mathbf{L}_{1}$ & -83.87 & -69.15 & 49.60 & 45.61 & 83.57 & 35.07 & -60.82 & 427.69 & 1.61 \\
\hline$F_{1} M_{2} L_{2}$ & -46.46 & 49.02 & 14.65 & 15.49 & 54.51 & -56.54 & -30.66 & 267.34 & 3.54 \\
\hline $\mathbf{F}_{1} \mathbf{M}_{2} \mathbf{L}_{3}$ & -218.42 & 175.83 & 78.92 & 35.10 & 224.37 & -258.52 & -37.29 & 1028.4 & 2.18 \\
\hline $\mathbf{F}_{2} \mathbf{M}_{1} \mathbf{L}_{0}$ & -68.20 & 24.04 & 101.48 & 28.99 & 50.71 & -94.94 & -42.08 & 410.45 & 2.15 \\
\hline $\mathbf{F}_{2} \mathbf{M}_{1} \mathbf{L}_{1}$ & -73.58 & 49.37 & 75.56 & 46.97 & 67.58 & -90.81 & -75.09 & 478.96 & 1.70 \\
\hline $\mathbf{F}_{2} \mathbf{M}_{1} \mathbf{L}_{2}$ & -87.02 & -37.24 & 27.85 & 5.11 & 90.74 & 9.28 & -8.71 & 265.95 & 4.67 \\
\hline $\mathbf{F}_{2} \mathbf{M}_{1} \mathbf{L}_{3}$ & -10.08 & -28.87 & 31.59 & 13.49 & 23.56 & 25.25 & -54.94 & 187.79 & 2.62 \\
\hline $\mathbf{F}_{2} \mathbf{M}_{2} \mathbf{L}_{0}$ & -83.25 & 79.02 & 103.78 & 39.29 & 58.35 & -160.76 & -36.43 & 560.89 & 2.52 \\
\hline $\mathbf{F}_{2} \mathbf{M}_{2} \mathbf{L}_{1}$ & -55.84 & -65.45 & 83.63 & 14.34 & 41.03 & 11.52 & -29.22 & 301.03 & 2.93 \\
\hline $\mathbf{F}_{2} \mathbf{M}_{2} \mathbf{L}_{2}$ & -0.37 & -0.40 & 8.57 & 7.93 & 0.11 & 0.68 & -16.52 & 34.58 & 6.24 \\
\hline $\mathbf{F}_{2} \mathbf{M}_{2} \mathbf{L}_{3}$ & -140.24 & 145.98 & 126.56 & 72.72 & 149.71 & -284.73 & -69.99 & 989.94 & 1.46 \\
\hline
\end{tabular}

shown in the same table the smallest NBI gives the high grain yield 6.24gm.pot ${ }^{-1}$ (figure3). The DRIS index of (P, Ca, Mg and K,) have decreased from $79.02,103.78,39.29,58.35$ to $-0.40,8.57,7.93,0.11$ for the above nutrient respectively, while the $\mathrm{N}, \mathrm{Fe}$ and total dry index which is increased from $-83.25,-160.76$ and -36.43 to- $0.37,0.68$ and-16.52, respectively. These results could be explanted on the base that the plant is grown with an adequate supply of Fe will make a rapid root and shoot development and subsequently increase the nutrient concentration in regular shape, because $\mathrm{Fe}, \mathrm{N}, \mathrm{P}, \mathrm{Mg}, \mathrm{Ca}$ and $\mathrm{K}$ are the prime constituent of protein, enzyme,DNA, RNA and the other compounds which play an important role in the physiological and biochemical process. Furthermore, when the plant is well supplied with Fe it leads to promoting the $\mathrm{CO}_{2}, \mathrm{NO}_{3}$ and $\mathrm{NH}_{3}$ assimilations mean while there is also the translocation of the photosynthesis from the leaves to the lower part increasingly because iron uptake enhanced the $\mathrm{K}$ uptake and the later play important role in translocation of food produced in leaves to root and other part of plants. But the probable reason is when excessive minerals are applied to the soil or to the plant, the soil is said to be saline and the plant growth may be restricted if these mineral ions reach the levels that limit water and the nutrient availability. Another important problem with excessive minerals is their accumulations in the soil which can cause sever toxicity.

Table (4): Combination effect of application methods ,types of Fe chelate and their concentration on nutrient index and NBI of lentil 


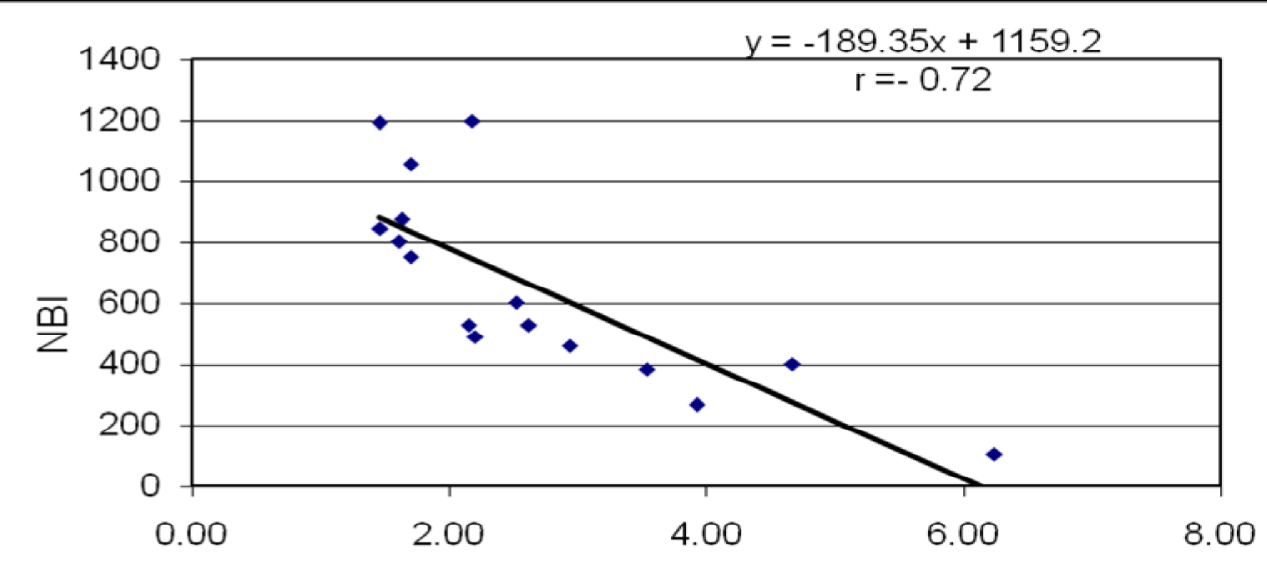

Total dry weight (gm/pots)

Fig(3): Relationship between NBI and total dry weight

According to DRIS chart figure (4) the point of the origin in the center of the chart represents the mean of each expression $\mathrm{N} / \mathrm{P}, \mathrm{N} / \mathrm{K}$ and $\mathrm{K} / \mathrm{P}$ for the population

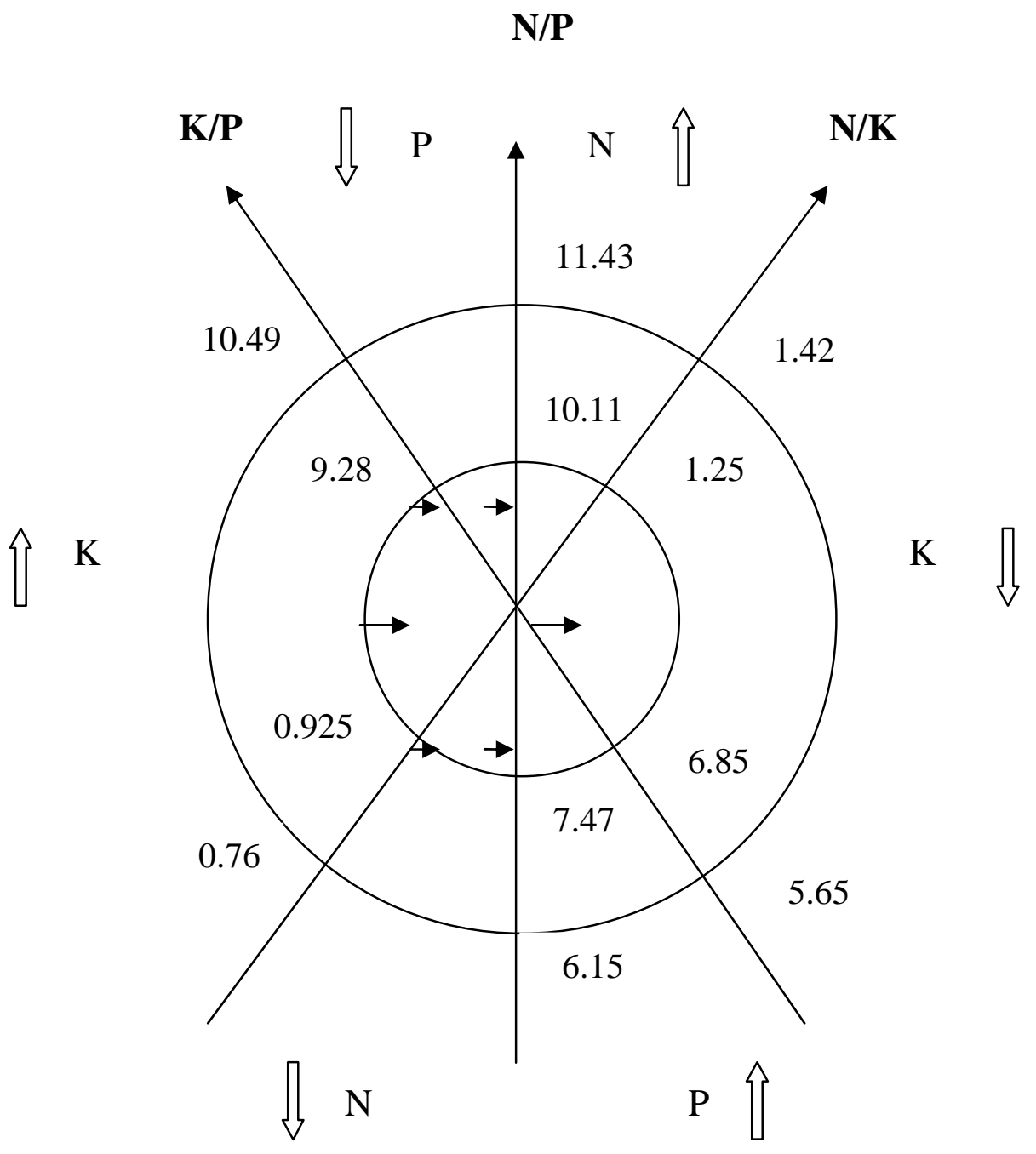

Fig (4): DRIS chart explain the optimum and critical values of some nutrients 
ratio

of high yielding plants, in other word, this is the composition desired in order to increase the chance of obtaining a high yield. However, this desired composition should not be considered as a single inflexible point but rather as a range encompassed by the inner of the two concentric circles. A plant composition failing with in this circles would be considered to be relatively balanced, which is denoted by a horizontal arrow, as one move away from the central zone along any axis the degree of imbalance between two elements increase. This zone of imbalance is divided into two subzone the first begin a zone of slight to moderate imbalance, this denoted by arrow at 45 degrees to the horizontal and is encompassed by the outer of the concentric circle, beyond this circles is a zone of marked imbalance denoted by the vertical arrow s being either too high or too low .

\section{ت Lens esculenta تأثير التسميد الورقي والأرضي للحديد المخلبي في الأتزان الغذائي للعداس

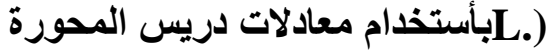

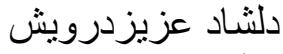 \\ قسم علوم البيئة|كليةعلوم|جامعةضصلاح الدين-أربيل|العراق}

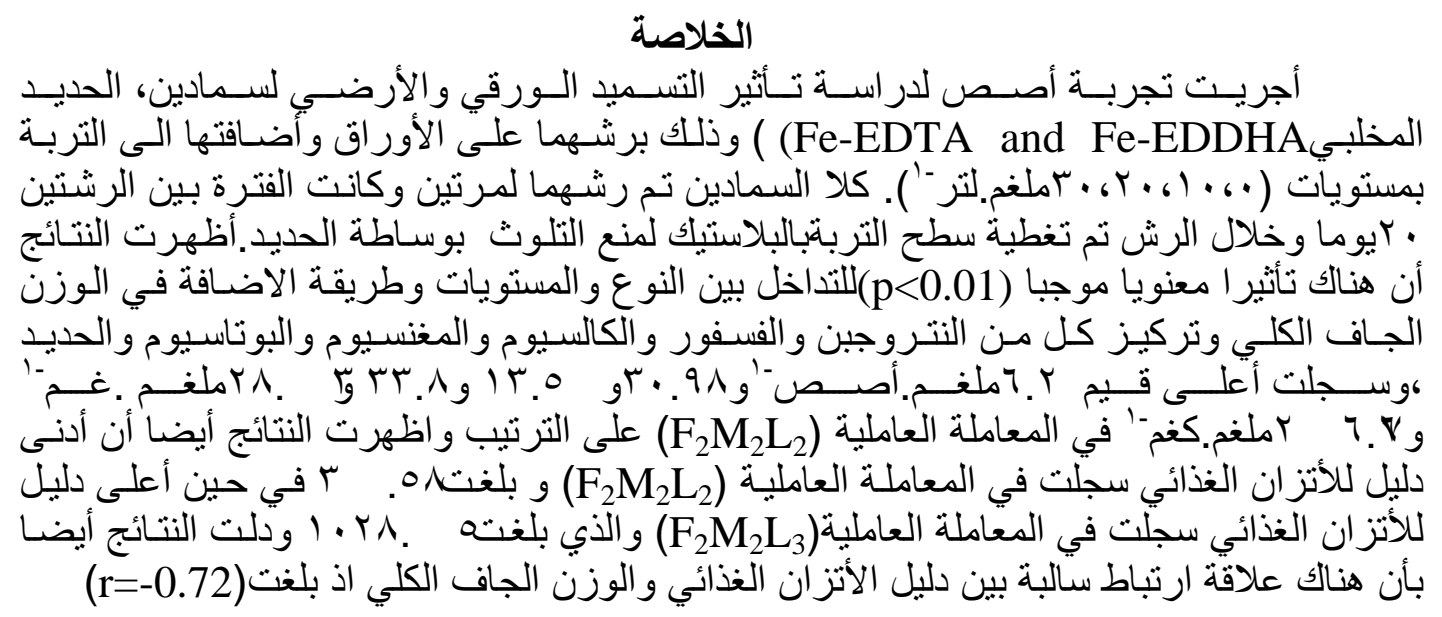

\section{REFERENCES}

AbouEl-NourE.A.A(2002). Growth and nutrient response of maize to foliar nutrition with micronutrients under irrigation with saline water .J.of Biological Sci.2(2) :92-97.

Al-Khafaji,S.K.M (1993). Interrelation of Magnesium With Zinc And Manganese In Plant Nutrition And Productivity Of Tomato And Cucumber Plants Under Heated Plastic House .Ph.D .Thesis .College of Agriculture . University of Baghdad.

Allen,S.E (1976).Chemical Analysis Of Ecological Materials. Blackwell Scientific Publications Osney Mead ,Oxford.P.500

Alpaslan, M. and S. Taban(1996). Zinc-iron relation in rice (Oryza sativaL.). Ankara University J. Agric. Sci. 2: 43-47.

Baflar, H. and A. Zgümüfl (1999). Effects of various iron fertilizers and rates on some micronutrient concentrations of peach trees. Tr. J. of Agriculture and Forestry, 23, 273-281. 
Baldock, J.O,and E.E.Schulte(1996). Plant analysis with standardized Scores combines DRIS and sufficiency range approaches for corn. J.of Agronomy. 88: 448-456.

Beverly,R.B(1993).A Practical Guide To The Diagnosis And Recommendation Integrated System (DRIS) Micro-Macro Publishing, Inc.Athens. GA:pp.385.

Black, C. A (1965). Method Of Soil Analysis.Agr.Mono9 Parts(1and2) .Amr.Soc.Agrc. Inc.Pub.Maddison.Wisconson.USA.pp.1575

Bremner, J.M., C.S.Mulvaney (1982). Methods of Soil Analysis. Part 2. Agronomy Vol. 9, $2^{\text {nd }}$ Edition.American Journal of Soil Science. Society. Madison. WI. pp.595-624.

Cline, R.A(1962). Sampling techniques for determining leaf nutrient concentrations for strawberries. Annual Rept. Vineland Hort.Expt. Sta. and Prod. Lab. (Ontario) 19-27.

Dara, S.T, P.E. Fixen, and R.H. Gelderman(1992). Sufficiency level and diagnosis and recommendation integrated system approaches for evaluating the nitrogen status of corn. J.of Agronomy. 84:1006-1010.

Esmail,A.O, K.K.Hamad and M.F.Yadgar(1999).Effect of Mg/Ca ratio in irrigated water on yield and quality of chick pea .Zanko J.11(2):11-17 ( in Arabic).

Hallmark,W.B, C.J.DeMooy and J. Pesek(1987).Comparison of two methods for diagnosing nutrient deficiencies .J.of Fertilizers Issues .4(4):151-158.

Havlin, J.L., J.D. Beaton, S.L. Tisdale and W.L. Nelson(1999). Soil Fertility and Fertilizers: An Introduction to Nutrient Management.

Horesh, I. and Y. Levy(1981). Response of Fe-deficient citrus trees to foliar Fe sprays with a low-surface-tension surfactant. Sci. Hortic.15: 227-233.

Jones, J.B(1993). Modern interpretation system for soil and plant analysis in the USA. Australian J. of Experiment Agriculture . 33: 1039-1043.

Karaman, M.R., A.R. Brohi, A. Inal and S. Taban (1997). Effect of iron and zinc applications on growth and concentration of mineral nutrients of bean (Phaseolus vulgaris L.) grown in artificial situation soils. Tr. J. of Agriculture and Forestry.23:341-348.

Kksal, I., H. Dumanolu., N.T. Günefl and M. Aktafl(1999). The effects of different amino acid chelate foliar fertilizers on yield, fruit quality, shoot growth and Fe, $\mathrm{Zn}, \mathrm{Cu}, \mathrm{Mn}$ concentration of leaves in williams pear cultivar (Pyrus communis L.). Tr. J.of Agriculture and Forestry.23: 351-358.

Pansu,M and J.Gautheyrou (2006). Handbook Of Soil Analysis. Springer-Verlag Berlin Heidelberg pp:1-993.

Rosell, R.A , J.A. Galantini , J.O. Iglesias, and R. Miranda(1992).Effect of sorghum residues on wheat productivity in semi-arid Argentina. I. Stover decomposition and $\mathrm{N}$ distribution in crop . Environmental Sci. 118 :253261.

Schuffelen,A.A.M and J.G.H Vanschauwenburg (1961).Quick testes for soil and plant analysis used by small laboratories .Netherland Journal of Agriculture Science .9:2-16.

Soltanpour, P.N ,M.J.Malakouti and A .Ronaghi(1995). Comparison of diagnosis and recommendation integrated system and nutrient sufficient range of corn. Soil Science Society of American J . 59: 133-139. 
Steele, R. G and J, H. Torrie (1969). Principle And Procedure Of Statistic .McGraw Hill Book Co.Inc.New York.pp.1-530

Sultan, M. Y (2005). Effect of Bacterial Inoculation And Chemical Fertilizers On Lentil (Lens culinaris) By Using The Diagnosis And Recommendation Integrated System (DRIS). Ph.D. Thesis. College of Agriculture. University of Mosul.

Sumner, M.E (1981). Diagnosing the sulfur requirement of corn and wheat using foliar analysis. J.of Agronomy .45: 87-90.

Wikoff, L. and J.T. Moraghan (1986). Different iron-manganese relationships in two flax cultivars. J. Plant Nutrition. 9(37):839-849. 